Fitofarmaka, Vol.9, No.1, Juni 2019 ISSN:2087-9164

\title{
UJI AKTIVITAS ANTIBAKTERI SEDIAAN FACE WASH GEL LENDIR BEKICOT (Achatina fulica) DAN KOPI ROBUSTA (Coffea canephora) TERHADAP \\ BAKTERI Staphylococcus aureus
}

\author{
Novi Fajar Utami, Sara Nurmala, Cantika Zaddana, Rizqi Aulia Rahmah \\ Program Studi Farmasi FMIPA Universitas Pakuan Bogor \\ Email:novi.utami@unpak.ac.id
}

\begin{abstract}
ABSTRAK
Jerawat adalah masalah yang umum terjadi pada usia remaja dan dewasa karena adanya peradangan dan peningkatan produksi sebum pada kulit, diperparah dengan infeksi bakteri diantaranya Staphylococcus aureus. Penelitian ini bertujuan untuk menentukan formula terbaik sediaan face wash gel dari lendir bekicot dan kopi robusta berdasarkan uji hedonik dan menentukan aktivitas antibakteri sediaan face wash gel terhadap bakteri penyebab jerawat Staphylococcus aureus dengan kontrol positif sediaan facial wash komersial. Akivitas antibakteri ditentukan dengan menentukan Konsentrasi Hambat Minimum (KHM) menggunakan metode dilusi padat dan mengukur Lebar Daya Hambat (LDH) menggunakan metode difusi cakram. Dari hasil penelitian diperoleh nilai KHM dari ekstrak kopi berada pada konsentrasi $15 \%$. Konsentrasi tersebut digunakan sebagai acuan pada pembuatan formula sediaan face wash gel dengan tiga perbedaan konsentrasi kopi F1 (5\%), F2 (10\%), F3 (15\%) dan satu konsentrasi lendir bekicot (12,5\%). Berdasarkan hasil uji hedonik, formula 3 merupakan formula yang paling disukai panelis. Pada pengujian terhadap bakteri Staphylococcus aureus formula 3 menunjukkan aktivitas antibakteri tertinggi dengan LDH sebesar 9,160 mm dan memberikan hasil yang tidak berbeda nyata dengan kontrol positif.
\end{abstract}

Kata Kunci :Bekicot, kopi robusta, face wash gel, Staphylococcus aureus

\section{ANTIBACTERIAL ACTIVITIES OF FACE WASH GEL SLICES BEKICOT (Achatina fulica) AND KOPI ROBUSTA (Coffea canephora) AGAINST BACTERIA Staphlococcus aureus}

\begin{abstract}
Acne is a common problem in adolescents and adults due to inflammation and increased production of sebum in the skin, compounded by bacterial infections including Staphylococcus aureus. This study aims to determine the best formula for face wash gel from snail mucus and robusta coffee based on hedonic tests and determine the antibacterial activity of face wash gel preparations against acne-causing bacteria Staphylococcus aureus with positive control of commercial facial wash preparations. Antibacterial activity was determined by determining the Minimum Inhibitory Concentration (MIC) using the solid dilution method and measuring the Inhibition Zone using the disk diffusion method. From the results of the study obtained the MIC value
\end{abstract}


of coffee extracts was at a concentration of $15 \%$. The concentration was used as a reference in making face wash gel formulations with three different concentrations of coffee F1 (5\%), F2 (10\%), F3 (15\%) and one concentration of snail slime $(12.5 \%)$. Based on the hedonic test results, formula 3 is the panelist's most preferred formula. In testing the Staphylococcus aureus formula 3 bacteria showed the highest antibacterial activity with Inhibition Zone of $9,160 \mathrm{~mm}$ and gave results that were not significantly different from positive controls.

Keywords: Snail, robusta coffee, face wash gel, Staphylococcus aureus

\section{PENDAHULUAN}

Jerawat merupakan penyakit kulit yang terjadi akibat adanya peradangan menahun kelenjar polisebasea yang ditandai dengan adanya komedo, papul, putsul, nodus, dan kista pada tempat predileksi (Mutschler, 1991). Bakteri yang dapat menyebabkan terjadinya jerawat adalah Staphylococcus epidermidis, Staphylococcus aureus, dan Propionibacterium acnes (Djajadisastra, 2009). Bakteri tersebut dapat menyebabkan iritasi epitel folikel dan memperparah terjadinya jerawat (Noventi, 2016). Pengobatan jerawat dapat dilakukan dengan memperbaiki abnormalitas folikel, menurunkan produksi sebum yang berlebih, menurunkan jumlah koloni bakteri penyebab jerawat dan menurunkan inflamasi pada kulit (Mitsui, 1997).

Lendir bekicot mengandung glycosaminoglycan berfungsi mengikat senyawa pemutus ikatan peptida, serta protein achasin pada bekicot memiliki fungsi biologik, yaitu pengikat protein (enzim) bakteri. Berdasarkan penelitian Anggraeni (2017) menyatakan bahwa lendir bekicot pada konsentrasi 20\% memiliki daya hambat yang baik terhadap Staphylococcus aureus. Penelitian selanjutnya oleh Mardiana (2015) menyatakan bahwa lendir bekicot pada konsentrasi $11 \%$ memiliki aktivitas antibakteri terhadap Propionibacterium acnes

Penambahan antioksidan pada akan membantu mengurangi radikal bebas yang mencegah terjadinya penuaan dini serta efek inflamasi pada kulit sehingga kulit (Sowmya, 2015). Penelitian Wigati (2017) menyatakan bahwa penggunaan biji kopi robusta berfungsi sebagai antioksidan dan mengandung protein yang berkhasiat melembabkan dan menghaluskan kulit serta memiliki nilai aktivitas antioksidan dengan nilai $\mathrm{IC}_{50} 54,14 \mathrm{ppm}$. Kemudian menurut Yaqin dan Nurmilawati (2015) setelah pemberian ekstrak etanol kopi robusta pada konsentrasi minimal $20 \%$ dapat menghambat pertumbuhan dari bakteri Staphylococcus aureus.

Oleh karena itu diperlukan suatu sediaan yang dapat digunakan sebagai perawatan kulit secara continue untuk merawat dan mencegah terjadinya jerawat. Maka dibuat sediaan face wash gel yang bertujuan untuk membersihkan wajah dan mempermudah penggunaan dan perawatan. Dengan penambahan kopi robusta diharapkan memberikan efek antioksidan dan memiliki efek antibakteri lebih tinggi apabila di kombinasikan dengan lendir bekicot sehingga kulit terlihat lebih cerah dan terbebas dari jerawat.

\section{METODE KERJA \\ Waktu dan Tempat Penelitian}

Penelitian ini dilakukan selama enam bulan, mulai dari bulan Agustus hingga Meret 2019 di Laboratorium Farmasi, FMIPA Universitas Pakuan. 


\section{Alat dan Bahan}

Alat yang digunakan adalah elektrik shock, alat-alat gelas, kain batis, viscometer Brookfield RV, Incubator, mikro pipet, Autoklaf, penangas, Rotary vacuum dryer.

Bahan yang digunakan adalah air suling, ammonium, asam klorida, bekicot, biji kopi robusta, larutan Bouchard, Carbopol 940, Dragendroff, Etanol 96\%, kertas cakram, klindamisin gel, larutan $10 \%$ gelatin, larutan Mayer, Methyl paraben, Mueller-Hilton Agar (MHA)Blood, Metanol, $\mathrm{NaCl}, \mathrm{pH}$ universal, propyl paraben, propylene glycol, sodium lauryl sulphate, trietanolamin.

\section{Pengumpulan Lendir Bekicot}

Bekicot yang digunakan pada penelitian ini diperoleh dari kebun yang berada di sekitar kampus Institut Pertanian Bogor, Dramaga, Bogor. Kemudian dideterminasi di Pusat Penelitian Bioteknologi-LIPI, Bogor. Setelah dilakukan determinasi. Dilakukan pengambilan lendir bekicot menggunakan metode Berniayanti et al. (2007) Lendir bekicot diambil menggunakan metode elektrik shock dengan aliran listrik dari 4.5-12 volt pada 1,5 ampere selama 60 detik. Lendir bekicot yang di dapat kemudian ditambahkan air dengan perbandingan (2:1). Disaring dengan kain batis. Bekicot yang telah diberikan perlakuan kemudian digunakan sebagai pakan itik.

\section{Pengumpulan Biji Kopi Robusta}

Biji kopi robusta yang digunakan dalam penelitian ini adalah berasal dari perkebunan kopi robusta yang berada di Garut, Jawa Barat. Kemudian determinasi tanaman akan dilakukan di Lembaga Ilmu Pengetahuan Indonesia (LIPI), Kebun Raya Bogor.

\section{Ekstraksi Biji Kopi Robusta}

Pembuatan ekstrak menggunakan metode maserasi dengan pelarut etanol 96\%. Ditimbang masing-masing $100 \mathrm{~g}$ sampel untuk dimaserasi dengan etanol 96\% teknis sebanyak 1 L. Direndam selama 6 jam pertama sambil sesekali diaduk, lalu didiamkan selama 18 jam. Kemudian disaring dan dipisahkan filtrat dan residunya. Residu hasil maserasi pertama diremaserasi kembali dengan $1 \mathrm{~L}$ etanol $96 \%$ dengan perlakuan yang sama. Lalu filtrat hasil maserasi pertama dan kedua digabungkan. Filtrat diuapkan hingga diperoleh ekstrak kental (DepKes RI, 2013).

\section{Uji Karakteristik Ekstrak Uji Organoleptik}

Deskripsi organoleptik serbuk dan ekstrak kopi robusta adalah pengamatan bentuk, warna, bau dan rasa dari kopi (Depkes, 2008).

\section{Kadar Air}

Penentuan kadar air dilakukan dengan menggunakan moisture analyzer. Sampel ditimbang seksama sebanyak 1 gram kedalam alat yang telah disiapkan. Kemudian kadar yang tertera pada moisture analyzer dicatat. Dilakukan pengulangan 2 kali (duplo).

\section{Kadar Abu}

Bahan uji ditimbang dengan seksama 2-3 gram, kemudian dimasukan ke dalam krus silikat yang telah dipijar dan ditara, diratakan. Dipijarkan pada suhu $\pm 600^{\circ} \mathrm{C}$ perlahan-lahan hingga arang habis, kemudian didinginkan dan ditimbang hingga bobot konstan $\pm 0,25 \%$. Jika dengan cara ini arang tidak dapat dihilangkan, ditambahkan air panas, diaduk, dan disaring. Dimasukkan filtrat ke dalam krus, diuapkan dan dipijarkan hingga bobot konstan. Kadar abu total dihitung terhadap bahan yang telah dikeringkan di udara. Dilakukan 
pengulangan 2 kali (duplo) (Depkes, 2008).

\section{Penapisan Fitokimia}

Identifikasi Flavonoid

Identifikasi menggunakan peaksi warna dengan beberapa pereaksi flavonoid, yaitu:

a. Uji Shinoda, Larutan uji diuapkan hingga kering, ditambahkan 2-3 tetes etanol, kemudian ditambah dengan serbuk $\mathrm{Mg}$ dan beberapa tetes asam klorida $5 \mathrm{M}$.

b. Larutan uji diuapkan hingga kering, ditambahkan 2-3 tetes etanol, kemudian ditambah dengan serbuk $\mathrm{Zn}$ dan beberapa tetes asam klorida $5 \mathrm{M}$ (Hanani, 2015).

\section{Identifikasi Tanin}

Sebanyak 2 gram sampel diekstraksi dengan etanol $80 \%(30 \mathrm{ml})$ selama 15 menit, kemudian disaring. Filtrat yang didapat diuapkan diatas penangas. Ditambahkan aquadest panas pada sisa penguapan dan diaduk, setelah dingin larutan disentrifugasi. Dipisahkan cairan atas dengan cara dekantasi dan larutan digunakan sebagai larutan percobaan yang akan digunakan dalam pengujian berikut :

1. Filtrat ditambahkan larutan $10 \%$ gelatin, akan terdapat endapan putih

2. Filtrat ditambahkan NaCl-gelatin (larutan $1 \%$ gelatin dalam $10 \% \mathrm{NaCl}$ dengan perbandingan 1:1). Terdapat endapan

3. Filtrat ditambahkan larutan $3 \%$ besi (III) klorida, terjadi warna hijau biru hingga kehitaman (Hanani, 2015).

\section{Identifikasi Alkaloid}

Sampel ditimbang $1 \mathrm{gr}$ dikocok dengan $20 \mathrm{ml}$ methanol dan $3 \mathrm{ml}$ ammonia, dipanaskan pada suhu 60C sambal dikocok 15 menit. Larutan disaring, lalu filtrat dipekatkan hingga lebih kurang $3 \mathrm{ml}$, kemudian ditambah $5 \mathrm{ml}$ asam klorida 1N. Larutan diteteskan pada 2 kaca arloji masing masing 3 tetes, dan ditambahkan pereaksi Dragendorff, Mayer, Bouchard (Hanani, 2015).

\section{Identifikasi Saponin}

Ekstrak kental sebanyak $10 \mathrm{ml}$ dikocok vertical di dalam tabung reaksi selama 10 detik, kemudian dibiarkan selama 10 detik. Saponin ditunjukan dengan terbentuknya busa setinggu 1$10 \mathrm{~cm}$ yang stabil selama tidak kurang dari 10 menit. Pada penambahan 1 tetes $\mathrm{HCl}$ 2N busa tidak hilang (DepkesRI, 1995).

\section{Uji Aktivitas Antibakteri Ekstrak}

Uji aktivitas ekstrak dilakukan dengan metode dilusi agar, terdiri dari 5 konsentrasi ekstrak kopi $(10 \%, 15 \%, 20 \%$, $25 \%, \quad 30 \%)$. Bakteri yang sudah diencerkan sesuai kekeruhan Mc Farland diambil $1 \mathrm{~mL}$ disebar diatas permukaan agar kemudian $1 \mathrm{~mL}$ konsentrasi ekstrak dimasukan ke dalam masing-masing cawan petri lalu cawan petri digerakkan secara melingkar yang diharapkan bakteri tersebar merata lalu diinkubasi pada suhu $37{ }^{\mathrm{O}} \mathrm{C}$ selama 18-24 jam. Konsentasi terendah pada sampel yang terhambat pertumbuhan bakterinya merupakan KHM (konsentrasi hambat minimum).

\section{Pembuatan Sediaan Face wash gel}

Formulasi face wash gel dibuat berdasarkan penelitian Sownmya (2015) dengan modifikasi penggunaan konsentrasi lendir bekicot dan ekstrak kopi berdasarkan hasil uji pendahuluan aktivitas antibakteri. Berikut formula dapat dilihat pada tabel 1 .

Dikembangkan Carbopol ultrez 20 dengan aquabidest panas, kemudian diaduk hingga homogen. Dicampurkan Carbopol ultrez 20 dengan trietanolamin. Kemudian ditempat berbeda di campurkan phenoxyethanol dengan propilen glikol sampai larut lalu ditambahkan sodium lauril sulfat hingga homogen. Setelah tercampur bagian Carbopol dan pengawet 
dicampurkan hingga homogen. robusta sedikit sedikit dan di aduk sampai Selanjutnya ditambahkan ekstrak kopi homogen.

Tabel 1. Formulasi Face Wash Gel Lendir Bekicot dan Ekstrak Kopi

\begin{tabular}{|c|c|c|c|c|c|}
\hline \multirow[b]{2}{*}{ Bahan } & \multicolumn{5}{|c|}{ Konsentrasi (\%) } \\
\hline & F 0 & F I & F II & F III & $\begin{array}{c}\text { Kontrol } \\
(+)\end{array}$ \\
\hline Ekstrak Kopi Robusta & - & 5 & 10 & 15 & \\
\hline Bekicot & - & 12,5 & 12,5 & 12,5 & \\
\hline Carbopol Ultrez 20 & 1 & 1 & 1 & 1 & \\
\hline Triethanolamine & 2 & 2 & 2 & 2 & Garnier $^{\circledR}$ \\
\hline Phenoxyethanol & 1 & 1 & 1 & 1 & face wash \\
\hline Propylene glycol & 20 & 20 & 20 & 20 & gel \\
\hline Sodium lauryl sulphate & 1 & 1 & 1 & 1 & \\
\hline Aquabidest & Ad 100 & Ad 100 & Ad 100 & Ad 100 & \\
\hline
\end{tabular}

\section{Evaluasi Sediaan Gel}

Evaluasi sediaan face wash gel dilakukan dengan mengacu pada metode Grace et al., (2015). Pengujian sifat fisik meliputi uji organoleptis, uji homogenitas, pengukuran $\mathrm{pH}$ dan pengukuran viskositas.

\section{Pengamatan Organoleptis}

Pemeriksaan organoleptik dilakukan meliputi pemeriksaan bentuk, homogenitas, warna dan bau secara visual dari sediaan face wash gel.

\section{Pengukuran pH}

Pengukuran $\mathrm{pH}$ dilakukan dengan menggunakan $\mathrm{pH}$ Meter $\mathrm{pH}$ sediaan gel harus sesuai dengan $\mathrm{pH}$ kulit.

\section{Pengukuran Viskositas}

Pengukuran viskositas dilakukan dengan menimbang $100 \mathrm{ml}$ gel ke dalam beaker glass kemudian diukur dengan viscometer brookfield dengan mengatur kecepatan dan spindle yang akan digunakan.

\section{Pengujian Homogenitas}

Uji homogenitas dilakukan dengan cara tiap formula face wash gel ditimbang sebanyak 0,1 gram. Diletakkan pada object glass, kemudian diamati di bawah mikroskop pada perbesaran 100 kali.

\section{Uji Hedonik}

Panelis sebanyak 20 orang mengemukaan tanggapan pribadi (subyektif) terhadap face wash gel lendir bekicot dan ekstrak kopi. Untuk mengukur perasaan suka atau tidak suka terhadap gel sabun pembersih wajah, digunakan skala hedonik dengan tingkatan 1-5 yang berturut-turut mewakili perasaan sangat tidak suka, tidak suka, ragu-ragu, suka, sangat suka. Atribut yang diamati pada sediaan gel sabun pembersih wajah lendir bekicot dan pati bengkuang adalah warna, aroma, tekstur.

\section{Uji Aktivitas Antibakteri Sediaan Face Wash Gel}

Menggunakan metode difusi cakram untuk menentukan Lebar Daerah Hambat (LDH) dari setiap formula. Disiapkan 20 $\mathrm{mL}$ median NA cair kemudian dicampurkan dengan bakteri yang sudah diencerkan berdasarkan kekeruhan McFarland sebanyak $1 \mathrm{~mL}$ kemudian ditunggu hingga memadat, kemudian diletakkan kertas cakram yang telah direndam dalam formula 0 , formula 1 , formula 2, formula 3, formula 4 , dan kontrol positif (Garnier ${ }^{\circledR}$ face wash $\mathrm{gel}$ ). Kemudian diinkubasi pada suhu $37{ }^{\mathrm{O}} \mathrm{C}$ selama 18-24 jam. Inkubasi dilakukan pada suhu $37^{\circ} \mathrm{C}$ selama $18-24$ jam. Lalu 
diamati lebar daerah hambat dengan menggunakan jangka sorong.

\section{Analisis Data}

Analisis data dilakukan agar diketahui aktivitas LDH dan Hedonik formulasi Face wash gel kopi robusta terbaik. Menggunakan analisis rancangan acak lengkap (RAL) pola faktorial. Apabila terdapat perbedaan pada setiap kelompok kemudian dilakukan uji lanjut Duncan.

\section{HASIL DAN PEMBAHASAN Determinasi Bahan}

Bahan yang digunakan pada penelitian ini adalah biji kopi robusta yang diperoleh dari daerah Temanggung dan dideterminasi di Herbarium Bogoriense Pusat Penelitian Botani, Lembaga Ilmu Pengetahuan Indonesia (LIPI) Komplek CSC-LIPI Jl. Raya Bogor Km 46, Cibinong 16911, Bogor, Jawa Barat. Hasil determinasi menunjukan bahwa bahan yang digunakan merupakan kopi robusta dengan nama latin Coffea canephora Pierre dari suku Rubiaceae.

Biji kopi robusta yang digunakan merupakan hasil pengolahan secara roasting. Roasting atau penyangraian ini dilakukan dengan memanaskan biji kopi tanpa menggunakan bahan lain dengan suhu $180-240^{\circ} \mathrm{C}$ selama $15-20$ menit. Menurut penelitian Farah (2012) kopi yang diroasting memiliki kadar alkaloid yang lebih tinggi dibandingkan dengan green coffee dengan konsentrasi 2,4-2,5\%.

\section{Ekstrak Kering Biji Kopi Robusta}

Metode ekstraksi yang digunakan pada penelitian ini adalah metode maserasi. Pelarut yang digunakan untuk mengekstraksi adalah etanol $96 \%$. Penggunaan pelarut etanol $96 \%$ berdasarkan penelitian Utami et al. (2018) ekstrak kopi dari temanggung dengan metode ekstraksi maserasi menggunakan etanol $96 \%$ memiliki nilai $\mathrm{IC}_{50}$ sebesar $51,90 \mathrm{ppm}$.

Rendemen yang diperoleh dari ekstrak biji kopi robusta 14,92\%. Hasil ekstrak berbeda dengan hasil uji sebelumnya pada penelitian Utami et al. (2018) bahwa ekstrak biji kopi robusta yang berasal dari Temanggung dengan rendemen sebesar 10,97\%. Namun pada penelitian Pratiwi (2008) menyatakan bahwa ekstrak kopi robusta memiliki rendemen sebesar 16,139\% dan penelitian Runiansyah et al., (2017) 18,50\%. Hasil yang berbeda disebabkan karena perbedaan waktu pemanenan, suhu tumbuh. Hasil uji organoleptik ekstrak, didapat ekstrak kering dengan aromatik khas kuat dengan rasa pahit dan memiliki warna coklat kehitaman, hasil uji organoleptik tersebut tidak berbeda dengan yang telah dilakukan Pratiwi (2008).

\section{Lendir Bekicot}

Pengambilan lendir bekicot dilakukan dengan metode kejut listrik yang telah dilakukan oleh Berniyanti et al (2007). Peralatan listrik yang digunakan adalah baterai aki motor dengan tegangan $60 \mathrm{~V}$ dan dua buah kawat penghubung dan satu buah multitester. Multitester digunakan untuk memastikan apakah tegangan listrik tidak berubah setalah digunakan. Bekicot dikejut pada keadaan aktif, bekicot harus berada diatas gelas piala. Kemudian didapat lendir bekicot sebanyak $200 \mathrm{~mL}$.

\section{Kadar Air Ekstrak Kopi Robusta}

Penentuan kadar air ekstrak dilakukan untuk mengetahui besarnya kadar air yang terkandung dalam ekstrak, karena kadar air yang tinggi dapat menjadi media pertumbuhan mikroorganisme yang baik sehingga menyebabkan perubahan senyawa kimia yang terdapat di ekstrak. Hasil yang diperoleh dari penentuan kadar air yaitu $1,885 \%$. Menurut penelitian 
Utami (2017) kadar air ekstrak kopi robusta sebesar $4,14 \%$ dan menurut Pratiwi (2018) kadar air dari ekstrak kopi robusta sebesar $5,427 \%$. Hasil penentuan kadar air ini memenuhi syarat sesuai pada Departemen Kesehatan (1977) bahwa persyaratan kadar air simplisia kurang dari $10 \%$.

\section{Kadar Abu Ekstrak Kopi Robusta}

Penentuan kadar abu ekstrak dilakukan untuk mengetahui besarnya kandungan mineral yang terdapat pada ekstrak. Hasil yang diperoleh dari penentuan kadar abu yaitu 3,721\%. Menurut penelitian Utami (2017) kadar abu ekstrak kopi robusta sebesar 2,09\% kemudian menurut penelitian Sundari (2018) bahwa kadar abu dari ekstrak kopi robusta sebesar $2,18 \%$, hasil yang didapat tidak jauh berbeda dengan hasil yang didapat. Hasil penentuan kadar abu ini telah memenuhi persyaratan sesuai DepKes (2009) yang menyatakan bahwa kadar abu ekstrak tidak boleh lebih dari $10,2 \%$.

\section{Uji Fitokimia Ekstrak}

Pengujian fitokimia dilakukan untuk mengetahui senyawa yang terkandung dalam ekstrak biji kopi robusta. Berdasarkan uji fitokimia didapat hasil positif pada alkaloid, tanin, saponin dan flavonoid. Menurut Higdon (2006) bahwa kafein pada kopi berfungsi sebagai antibakteri pada staphylococcus aureus. Hasil tersebut sesuai dengan penelitian yang sudah dilakukan oleh Sundari (2018) bahwa ekstrak biji kopi robusta terdapat kandungan senyawa alkaloid, flavonoid, tannin, dan saponin.

Tabel 2. Uji Fitokimia Ekstrak Biji Kopi Robusta

\begin{tabular}{ll}
\hline Senyawa & Hasil \\
\hline Alkaloid & + \\
Flavonoid & + \\
Tanin & + \\
\hline
\end{tabular}

Saponin +

\section{Konsentrasi Hambat Minimum (KHM) Ekstrak Biji Kopi Robusta dan Lendir Bekicot}

Pengujian Konsentrasi Hambat Minimum (KHM) untuk mengetahui konsentrasi minimum suatu sampel dapat berfungsi menghambat bakteri. Metode yang digunakan adalah metode dilusi padat. Keuntungan metode ini yaitu satu konsentrasi agen mikroba yang diuji dapat digunakan untuk menguji beberapa mikroba (Pratiwi, 2008). Digunakan 5 deret konsentrasi ekstrak biji kopi robusta, $10 \%, 15 \%, 20 \%, 25 \%, 30 \%$. Hasil pengujian menunjukan bahwa konsentrasi $15 \%$ dapat menghambat pertumbuhan bakteri Staphylococcus aureus dengan tidak adanya bakteri yang tumbuh pada media ditandai dengan media yang jernih. Namun pada lendir bekicot tidak didapatkan KHM dengan tidak terbentuknya zona bening pada cawan petri.

\section{Formulasi Sediaan Face Wash Gel}

Pembuatan formula sediaan face wash gel didapatkan dari modifikasi formula yang dilakukan oleh Fatima (2015), modifikasi dilakukan agar mendapatkan sediaan yang dapat diterima oleh panelis. Pada formula yang dibuat Fatima (2015), gelling agent yang digunakan adalah Carbopol 940 namun pada penelitian ini digunakan Carbopol Ultrez 20, penggunaan Carbopol Ultrez 20 memiliki keuntungan yaitu proses pembasahan serbuknya relatif cepat sehingga dapat mengurangi waktu produksi selain itu berdasarkan COA dari Carbopol Ultrez 20, memiliki kekentalan yang lebih tinggi dibandingkan carbopol 940 sehingga dengan konsentrasi yang kecil sudah dapat menghasilkan kekentalan yang diinginkan. Pengawet yang digunakan sebelumnya merupakan pengawet yang sudah dikurangi pada 
sediaan kosmetik yaitu paraben sehingga pada formula diganti dengan phenoxyetanol. Penambahan ekstrak kopi robusta sebagai zat aktif yang berat bobotnya masing masing 5\% untuk formula 1, 10\% untuk formula 2, $15 \%$ untuk formula 3. Pada lendir bekicot digunakan konsentrasi 12,5\% berdasarkan penelitian (Berniyati, 2007). Perhitungan formula sediaan face wash gel dapat dilihat pada Lampiran 9. Hasil pembuatan sediaan face wash gel dapat dilihat pada Gambar 3.

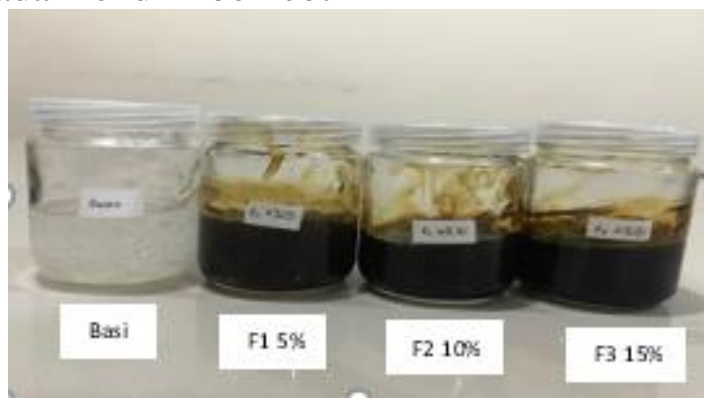

Gambar 3. Sediaan Face Wash Gel Lendir Bekicot dan Kopi Robusta

\section{Evaluasi Sediaan}

Hasil pengamatan organoleptik formula face wash gel memiliki karakteristik yang tidak berbeda, dikarenakan konsentrasi yang digunakan pada sediaan hanya terdapat pada penggunaan konsentrasi ekstrak kopi robusta. Hasil uji organoleptik dapat dilihat pada Tabel 3 .

Tabel 3. Hasil Uji Organoleptik Sediaan Face Wash Gel Kopi Robusta

\begin{tabular}{lllll}
\hline Parameter & \multicolumn{1}{c}{ F0 } & \multicolumn{1}{c}{ F1 } & \multicolumn{1}{c}{ F2 } & \multicolumn{1}{c}{ F3 } \\
\hline Tekstur & Kental & Agak kental & Agak Kental & Kental \\
\hline Warna & Bening & $\begin{array}{l}\text { Coklat } \\
\text { kehitaman }\end{array}$ & $\begin{array}{l}\text { Coklat } \\
\text { kehitaman }\end{array}$ & $\begin{array}{l}\text { Coklat } \\
\text { kehitaman }\end{array}$ \\
\hline Aroma & Aromatik & Aromatik & Aromatik khas & Aromatik \\
& khas lemah & khas lemah & lemah & khas kuat \\
\hline
\end{tabular}

Berdasarkan hasil pengujian organoleptik pada parameter tekstur didapat hasil yang berbeda karena semakin tinggi konsentrasi ekstrak kopi yang dipakai semakin kental juga sediaan yang didapat. Kemudian pada parameter aroma terdapat perbedaan, karena semakin tinggi konsentrasi ekstrak kopi yang digunakan semakin kuat aroma kopi yang dihasilkan. Pada formula 0 dihasilkan aroma aromatik khas lemah dari aroma SLS, formula 1 dan 2 aroma yang dihasilkan aromatik khas kopi yang lemah sedangkan pada formula 3 aromatik khas kopi kuat. Hal ini dapat disebabkan perbedaan dari konsentrasi yang digunakan.

\section{Uji pH}

Pengujian $\mathrm{pH}$ dilakukan untuk mengetahui $\mathrm{pH}$ dari sediaan yang sudah dibuat. Menurut Mappa (2013) pengujian $\mathrm{pH}$ bertujuan untuk melihat tingkat keasaman sediaan untuk menjamin sediaan tidak menyebabkan iritasi pada kulit. Berdasarkan hasil pengujian $\mathrm{pH}$ didapat hasil yang berbeda. Pada formula 0 (basis) yaitu 7,57, pada formula 1 nilai $\mathrm{pH}$ yang didapat yaitu 7,26, pada formula 2 nilai $\mathrm{pH}$ yang didapat yaitu 6,59, pada formula 3 nilai $\mathrm{pH}$ yang didapat 6,46 kemudian pada kontrol positif nilai $\mathrm{pH}$ yang didapat yaitu 5,22. Hasil uji $\mathrm{pH}$ terdapat perbedaan karena ekstrak kopi robusta memiliki sifat asam sehingga semakin tinggi konsentrasi yang 
digunakan maka $\mathrm{pH}$ yang dihasilkan akan semakin kecil atau asam.

Berdasarkan dari data yang didapat semua formula sudah memenuhi syarat pH sediaan sabun menurut SNI yaitu 6-8. Pengujian $\mathrm{pH}$ sediaan face wash gel dilakukan dengan menggunakan $\mathrm{pH}$ meter. Hasil nilai $\mathrm{pH}$ dapat dilihat pada Tabel 4.

Tabel 4. Hasil pengukuran $\mathrm{pH}$

\begin{tabular}{cc}
\hline Sediaan & Nilai pH \\
\hline Formula 0 & 7,57 \\
Formula 1 & 7,15 \\
Formula 2 & 6,48 \\
Formula 3 & 6,38 \\
4 (Sediaan di pasaran) & 5,22 \\
\hline
\end{tabular}

\section{Pengujian Homogenitas}

Pengujian homogenitas dilakukan untuk mengetahui kehomogenan sediaan yang telah dibuat. Pengujian homogenitas dilakukan dengan cara meletakkan sediaan diantara 2 objectglass, pengamatan dilakukan dengan melihat adanya butiran butiran kasar pada kaca (Ditjen POM, 1985). Hasil pengamatan homogenitas sediaan face wash gel dari ketiga formula tersebut adalah homogen. hal ini disebabkan karena ekstrak kopi robusta larut dalam basis dan dapat bercampur dengan baik dengan bahan lain.

\section{Pengujian Viskositas}

Pengujian viskositas tiap formula dilakukan menggunakan Viscometer Brookfield menggunakan spindle 5 pada kecepatan putar 50 RPM, penggunaan spindle dan RPM berdasarkan nilai torsi yang mendekati 100\%. Nilai viskositas dapat dilihat pada tabel 5 .

Tabel 5. Nilai Viskositas Sediaan Face Wash Gel Kopi Robusta

\begin{tabular}{cc}
\hline Formula & $\begin{array}{c}\text { Viskositas } \\
\text { (cPoise) }\end{array}$ \\
\hline 0 & 7252 \\
1 & 7328 \\
2 & 7362 \\
3 & 7469 \\
4 (Sediaan di pasaran) & 3918 \\
\hline
\end{tabular}

Berdasarkan hasil menunjukan bahwa semakin tinggi ekstrak kopi yang digunakan maka nilai viskositas akan semakin meningkat. Kemudian sediaan yang ada dipasaran memiliki viskositas yang lebih rendah dibanding sediaan yang dibuat.

\section{Uji Kesukaan (Hedonik)}

Parameter yang digunakan pada uji kesukaan yaitu aroma, tekstur dan warna dari sediaan face wash gel. Pengujian dilakukan menggunakan 20 panelis wanita berusia 19-21 tahun. Hasil uji kesukaan dapat dilihat pada Tabel 6.

Tabel 6. Hasil Uji Kesukaan Sediaan Face Wash Gel

\begin{tabular}{ccccc}
\hline Formula & \multicolumn{3}{c}{ Rata - Rata } & Rata- \\
& Aroma & Warna & Tekstur & Rata \\
\hline F1 & $2,45^{\mathrm{a}}$ & $3,00^{\mathrm{a}}$ & $2,55^{\mathrm{a}}$ & 8 \\
\hline F2 & $2,75^{\mathrm{ab}}$ & $3,00^{\mathrm{a}}$ & $2,90^{\mathrm{ab}}$ & 8,65 \\
\hline F3 & $2,95^{\mathrm{bc}}$ & $3,10^{\mathrm{a}}$ & $3,10^{\mathrm{b}}$ & 9,15 \\
\hline
\end{tabular}

Keterangan : angka yang diikuti huruf yang sama dalam kolom yang sama menyatakan tidak ada perbedaan nyata antara formula berdasarkan uji lanjut Duncan pada taraf $\alpha 0,05$.

Berdasarkan data diatas dapat dilihat parameter warna dari semua formula disukai oleh panelis ditandai dengan subset yang sama. Selain itu parameter lainnya seperti aroma dan tekstur, pada formula 3 lebih banyak disukai oleh panelis, namun formula 2 berada pada subset yang sama dengan formula 3 yang 
artinya berdasarkan efisiensi penggunaan bahan, formula 2 sudah cukup disukai oleh panelis. Dilihat dari ke tiga parameter tersebut formula 3 merupakan formula yang paling disukai oleh masyarakat dan formula 2 merupakan formula yang paling efisien namun tetap disukai panelis.

\section{Pengujian Lebar Daya Hambat (LDH) Sediaan Face Wash Gel}

Pengujian Lebar Daya Hambar (LDH) dilakukan untuk menentukan aktivitas antibakteri Staphylococcus aureus pada sediaan face wash gel dan kemudian dibandingkan dengan aktivitas antibakteri dari sediaan yang berada dipasaran. Pengujian antibakteri ini menggunakan metode kertas cakram dimana keuntungan dari metode ini adalah aktivitas dengan mudah dihitung dan hanya menggunakan kertas sebagai media sampel. Hasil uji aktivitas antibakteri sediaan face wash gel memiliki aktivitas antibakteri terhadap bakteri Staphylococcus aureus. Hal ini dapat dilihat pada hasil pengukuran Lebar Daya Hambat (LDH) yang terbentuk yaitu berupa zona bening yang terlihat pada sekitar kertas cakram. Berdasarkan hasil yang didapat sediaan face wash gel kopi robusta memiliki aktivitas antibakteri yang tidak berbeda nyata dengan Garnier ${ }^{\circledR}$ face wash gel yang merupakan sediaan yang sudah beredar dipasaran. Hasil pengujian LDH dapat dilihat pada Gambar 3

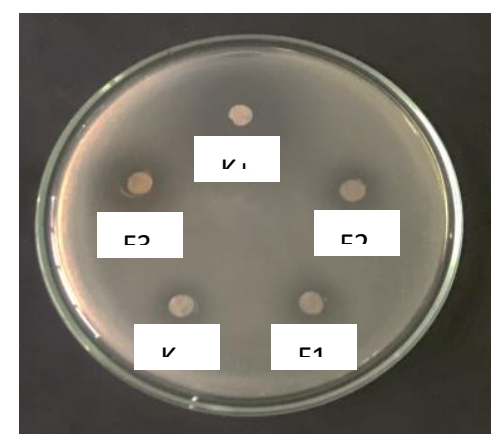

Gambar 3. LDH Sediaan Face Wash Gel

F1 $=$ Formula 1; F2 = Formula 2; F3 = Formula 3; $(-)=$ Kontrol negatif $;(+)=$ Kontrol PosItif $\left(\right.$ Garnier $^{\circledR}$ face wash gel)

Pada gambar 6 dapat dilihat bahwa setiap formula sediaan memiliki aktivitas antibakteri dengan menghambat pertumbuhan bakteri Staphylococcus aureus. Pada formula 1 dan 2 memiliki aktivitas penghambatan yang kecil karena semakin tinggi konsentrasi kopi robusta yang digunakan maka semakin besar lebar zona hambat yang terbentuk. Sedangkan basis memiliki zona hambat yang paling sempit. Terbentuknya zona hambat disekitar kertas cakram diduga karena sediaan face wash gel kopi robusta mengandung flavonoid, alkaloid, tanin dan saponin.
Menurut Setyaningrum alkaloid dapat mengganggu komponen penyusun peptidoglikan sel bakteri, yang menyebabkan lapisan dinding sel tidak terbentuk secara utuh dan menyebabkan kematian sel. Selain itu senyawa tanin dapat menyerang polipeptida dinding sel sehingga menyebabkan kerusakan pada bakteri dan senyawa saponin mempunyai molekul yang dapat melarutkan lemak atau lipofilik sehingga dapat menurunkan tegangan permukaan sel yang akhirnya menyebabkan hancurnya bakteri (Soetan, 2006). Cushnie (2003) menyatakan bahwa flavonoid memiliki efek antibakteri karena 
dapat menghambat sintesis asam nukleat, kemudian mengganggu fungsi membrane sitoplasma dan metabolisme energi bakteri. Kemudian pada penelitian Mori et al. (1987) bahwa flavonoid dapat menghambat sintesis DNA dan RNA pada bakteri Gram positif.

Nilai lebar diameter daya hambat yang diperoleh kemudian dianalisis menggunakan metode ANOVA kemudian apabila terdapat perbedaan dilakukan uji lanjut Duncan. Berdasarkan hasil terhadap penghambatan staphylococcus aureus memberikan hasil yang beda nyata. Hasil uji statistik dapat dilihat pada tabel 7 .

Tabel 7. Nilai Lebar Daya Hambat (LDH) Sediaan Face Wash Gel

\begin{tabular}{lll}
\hline Perlakuan & $\begin{array}{l}\text { Rata - Rata } \\
(\mathbf{c m})\end{array}$ & LDH \\
Kontrol - & $0,0850^{\mathrm{a}}$ & \\
Kontrol + & $1,0500^{\mathrm{d}}$ & \\
Formula 1 & $0,3750^{\mathrm{b}}$ & \\
Formula 2 & $0,5200^{\mathrm{c}}$ & \\
Formula 3 & $0,9160^{\text {cd }}$ & \\
\hline
\end{tabular}

Keterangan : angka yang diikuti huruf yang sama dalam kolom yang sama menyatakan tidak ada perbedaan nyata antara formula berdasarkan uji lanjut Duncan pada taraf $\alpha 0,05$.

Berdasarkan hasil uji lanjut Duncan menunjukan bahwa konsentrasi yang digunakan pada sediaan face wash gel memiliki pengaruh terhadap lebar daya hambat. Dari keenam perlakuan kontrol negatif memiliki sedikit penghambatan karena pada sediaan sudah terkandung pengawet yang diduga memili peran terhadap aktivitas antibakteri. Formula 3 memiliki aktivitas antibakteri yang paling baik dibandingkan formula lain kemudian hasil uji statistik, formula 3 memiliki hasil yang tidak berbeda nyata dengan kontol positif. Dengan bertambahnya konsentrasi kopi robusta maka nilai lebar daya hambat semakin meningkat.

\section{KESIMPULAN}

Formula sediaan face wash gel kopi robusta yang memiliki aktivitas antibakteri tertinggi terdapat pada formula 3 yaitu dengan penambahan ekstrak kopi robusta dengan konsentrasi $15 \%$ yaitu sebesar 9,160 mm.

Berdasarkan uji mutu fisik dan uji hedonik formula sediaan face wash gel yang disukai oleh panelis adalah formula 3 dengan konsentrasi $15 \%$.

\section{UCAPAN TERIMAKASIH}

LPPM, Universitas Pakuan, Yayasan Pakuan Siliwangi dan Kemenristek Dikti yang telah mendanai penelitian ini.

\section{DAFTAR PUSTAKA}

Anggraeni, D., S. Darmawati, E.T.W. Maharani. 2018. Profil Protein dan Daya Anti Mikroba Lendir Bekicot (Achatina fulica) terhadap Methicillin Resistant Staphylococcus aureus (MRSA). Prosiding Seminar Nasional Unimus. 1: 73-77.

Berniyanti, T., E.B. Waskito, S. Suwarno. 2007. Biochemival characterization of an antibactrial glycoprotein from Achatina fulica ferussac snail mucus local isolate and their implication on bacterial dental infection. Indonesian Journal of Biotechnology. (1): 943-951.

Cushnie, T., E S Hamilton, A.J. Lamb. 2003. Assessment of the antibacterial activity of selected flavonoids \& consideration of discrepancies between previous reports Microbiological Research. 158(4): 281-289.

Departemen Kesehatan Republik Indonesia. 1977. Materia Media Indonesia jILID 1. Jakarta : Departemen Kesehatan Republik Indonesia.

Departemen Kesehatan Republik Indonesia. 1995. Farmakope 
Indonesia Edisi IV. Jakarta : Departemen Kesehatan Republik Indonesia.

Departemen Kesehatan Republik Indonesia. 2008. Farmakope Herbal Indonesia Edisi I. Jakarta : Departemen Kesehatan Republik Indonesia.

Departemen Kesehatan Republik Indonesia. 2009. Farmakope Herbal. Jakarta : Departemen Kesehatan Republik Indonesia.

Departemen Kesehatan Republik Indonesia. 2013. Farmakope Herbal. Departemen Kesehatan Republik Indonesia.

Farah, Adriana. 2012. Coffee : Emerging Health Effects And Disease Prevention. John Willey \&Sons : Wiley- Blackwell Publising.

Hanani, E. 2015. Analisis Fitokimia. EGC. Jakarta.

Higdon, J.V. 2016. Coffee and health : A review of recent human research. $J$ Crit Rev Food SCI Nutr. 46(2): 101123.

Mappa T, J.E. Hosea, N. Kojong. 2013. Formulasi Gel Ekstrak Daun Sasalaahan dan uji efektivitasnya terhadap luka bakar pada kelinci (Oryctolagus cuniculus). J Pharmacon. Vol 2(2): 49-55.

Mardiana, Z.H. 2015. Formulasi gel yang mengandung lendir bekicot (Achatina fulica) serta uji aktivitas antibakteri terhadap

Propionibacterium acnes. Skripsi. Repositori Iniversitas Islam Bandung.

Mappa T, Hosea JE. 2013. Formulasi Gel

Ekstrak Daun Sasalaahan. $J$ Pharmacon. Vol 2:2. 49-55
Mitsui, T. 1997. New Cosmetic Science edisi 1. Amsterdam: Elsevier Science B.V.

Mori, A., C. Nishino, N. Enoki, S. Tawata. 1987. Antibacterial activity and mode of action of plant flavonoids against proteus vulgaris and Staphylococcus aureus. $J$ Phytochemistry. Vol 26(8): 22312234.

Mutschler, E. 1991. Dinamika Obat, Edisi $V$, terjemah Widianto, M.B. \& Ranti, A.S., Bandung : ITB Press.

Noventi, W. 2016. Potensi Ekstrak Daun Sirih Hijau (Piper betle L.) sebagai Alternatif Terapi Acnevulgaris. $J$ Maj 5.1: 140-145.

Pratiwi. S.T. 2008. Mikrobiologi Farmasi. Penerbit Erlangga. Jakarta.

Runiansyah, D. 2017. Kajian perbedaan suhu penyaduhan terhadap kadar polifenol kopi robusta (Coffea canephora). Skripsi. Universitas Pakuan. Bogor

Setyaningrum. 2003. Aktivitas antidiabetes ekstrak air dan etanol daun kaca piring. Tesis. ITB.

Soetan, K. O.. M.A. Oyekunle, O.O. Aiyelaagbe, M.A. Fafunso. 2006. Evaluation of the antimicrobial activity of saponins extract of Sorghum bicolor L. Moench. African Journal of Biotechnology. 5 (23)2405-2407.

Sowmya, K., V, Darsika. C, X. F. Grace, S. Shanmuganathan. 2015. Formulation and evaluation of a polyherbal face wash gel. World Journal of Pharmacy and Pharmaceutical Sciences 4(6): 585-588. 
Sundari, F. M. 2018. Aktivitas antiInflamasi ekstrak biji kopi robusta secara in vitro. Skripsi. Universitas Pakuan. Bogor.

Utami, N.V., N. Nhestricia, S. Maryanti, T. Tisya, S. Maysaroh. 2018. Uji aktivitas antioksidan kopi robusta (Coffea canephora) berdasarkan perbedaan ekologi dataran tinggi di Pulau Jawa. J Fitofarmaka. Vol 8(1): 60-65.
Wigati. 2017. Kandungan fenolik dan aktivitas antioksidan dari biji kopi robusta (Coffea canephora) di Provinsi Jawa Barat (Bandung, Bogor, Garut). Skripsi. Universitas Pakuan. Bogor.

Yaqin, M.A., M. Nurmilawati. 2015. Pengaruh ekstrak kopi robusta (Coffea canephora) sebagai penghambat pertumbuhan. Jurnal Seminar Nasional XII Pendidikan Biologi FKIP UNS. 